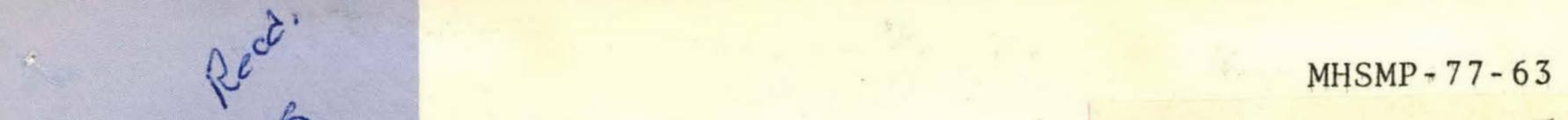

Dist. Category UC- 37

\title{
Pantex Model 121 Streak Camera
}

\author{
Gearge T. West
}

DEVELOPMENT DIVISION

OCTOBER 1977

Process Development

Endeavor No. 231

\section{(1)}

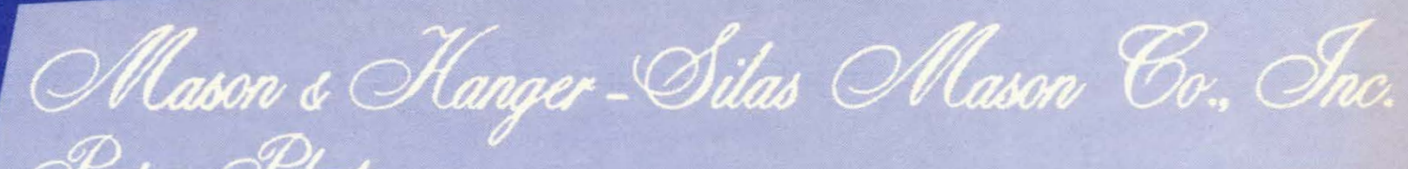
OPanar OPlans

ค. O. BOX 30020

AMARILLO. TEXAS 79177

806-335. 1581

oserated tor the 


\section{DISCLAIMER}

This report was prepared as an account of work sponsored by an agency of the United States Government. Neither the United States Government nor any agency Thereof, nor any of their employees, makes any warranty, express or implied, or assumes any legal liability or responsibility for the accuracy, completeness, or usefulness of any information, apparatus, product, or process disclosed, or represents that its use would not infringe privately owned rights. Reference herein to any specific commercial product, process, or service by trade name, trademark, manufacturer, or otherwise does not necessarily constitute or imply its endorsement, recommendation, or favoring by the United States Government or any agency thereof. The views and opinions of authors expressed herein do not necessarily state or reflect those of the United States Government or any agency thereof. 


\section{DISCLAIMER}

Portions of this document may be illegible in electronic image products. Images are produced from the best available original document. 


\section{NOTICE}

This report was prepared as an account of work sponsored by the United States Government. Neither the United States nor the United States Energy Research and Development Administration, nor their employees, nor any of their contractors, subcontractors, or their employees, makes any warranty, express or implied, or assumes any legal liability or responsibility for the accuracy, completeness or usefulness of any information, apparatus, product or process disclosed, or represents that its use would not infringe privately-owned rights.

Printed in the United States of America

Available from

National Technical Information Service

U. S. Department of Commerce

5285 Port Royal Road

Springfield, VA 22161

Price: Printed Copy $\$ 2 / .00$; Microfiche $\$ 3.00$ 


\title{
PANTEX MODEL IZI STREAK CAMERA
}

\author{
George T. West \\ DEVELOPMENT DIVISION \\ Process Development \\ Endeavor No. 231
}

\begin{abstract}
The internal optical system for the Pantex Model 121 Streak Camera was optimized at 1:1 magnification using tools and methods currently available at Pantex. The system performs well, with slight vignetting at small magnification $(0.2)$ with small apertures $(0.6 \mathrm{~cm}$ or less with $107 \mathrm{~cm}$ focal length objective lens).
\end{abstract}

\section{DISCUSSION}

A new internal optical system was desired for the Model $121(10 \mathrm{~cm} \mathrm{x}$ $25 \mathrm{~cm})$ streak camera designed and fabricated at Pantex. Utilization of lenses already available at the plant was the goal.' The final system was comprised of two internal lenses, with an aperture midway between them, and an external field lens. A previous camera, Model 101, was built using the $B$ and $W$ Model 168 as a basis for determining lens focal lengths, placements, etc. However, the magnification across the film was known to vary considerably, so a different approach was used for Model 121 .

A pair of two-element achromatic lenses purchased from A Jaegers (Part No. 8E1093/35C1479) was selected for the internal relay system. The lenses

(1) R. W. Ashcraft, G. T. West, "Improvement of Photographic and Optical Systems," MHSMP. 75-5R (Qctober-December 1974). were $8 \mathrm{~cm}$ diameter with a $71 \mathrm{~cm}$ focal length. Previous attempts (1) to determine MTF properties of these lenses and the overall system were thwarted by equipment limitations.

Thin-lens calculations showed that, for unit magnification, the lenses should be separated by $20.6 \mathrm{~cm}$. This arrangement yielded sharper results and a more constant magnification across the film than that of the Model 101.

Considerable experimentation was done to determine optimum orientation of the lenses and the effect of an aperture between them." The image was easiest to focus with the thicker elements facing each other and with a. $4.4 \mathrm{~cm}$ diameter aperture $5.2 \mathrm{~cm}$ ahead of the rear lens (see Fig. 1 diagram).

A diagram of the overall system is shown in Fig. 2. Using the measurements shown as a guide, reassembly of the optical system is possible with a final magnification of unity within one percent. Final focus of the slit plane image is achieved by moving the rear. 

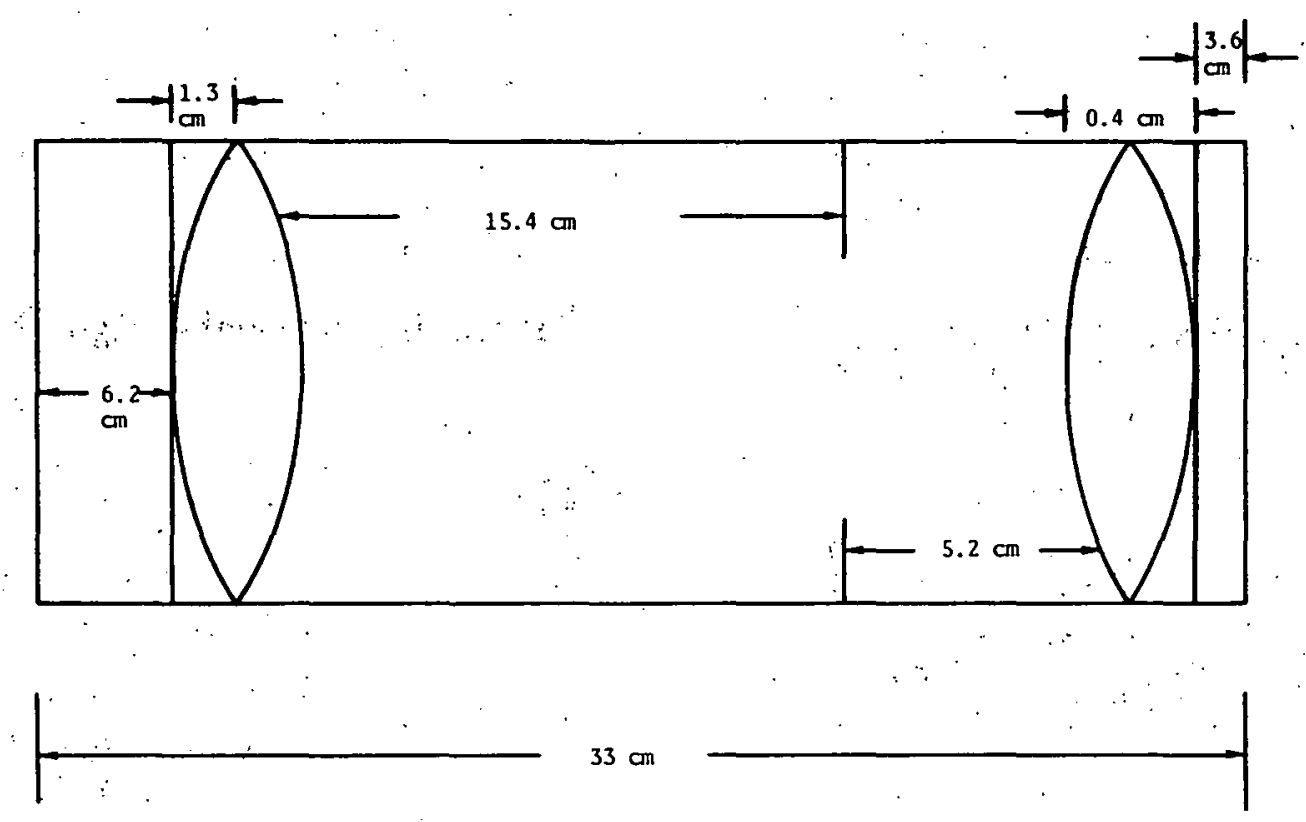

Fig. 1. Lens Barrel
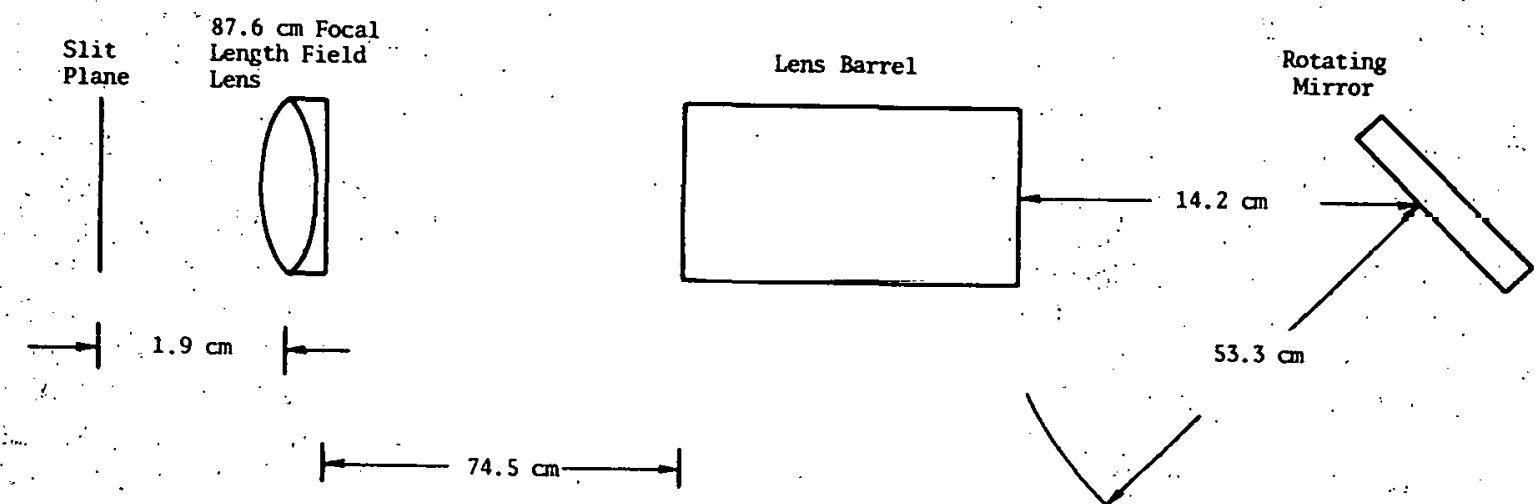

Fig. 2. Diagram of Overa11. System

lens toward or away from the slit. When the top and bottom of the slit plane target are in focus and the center portion is out of focus, the rear lens should be moved toward the slit.
Film records of a slit plate containing a transparent millimeter tape were made at the upstream and downstream still picture positions. The films and the slit plate were read four times in each direction on a 
Grant Comparator. Average calculations of magnification for both still pictures are plotted in Fig. 3. Note that the total variation in magnification across the film is approximately $0.7 \%$. There are only slight differences in the upstream and downstream positions.

A similar plot for the Model 101 upstream position is shown in Fig. 4. Note that the total variation in magnification across the film is approximately $1 \%$.

Best possible results (approximately $0.1 \%$ variation in magnification) were obtained without using the $87.6 \mathrm{~cm}$ field lens shown in Fig. 2. However, any field stop used with an objective lens became the system aperture, making the camera useful only wide open. The field lens was replaced with the thick (refers to center of elements) element toward the slit.

Some vignetting of a field inage is noticeable at magnifications smaller than 0.5 using moderate apertures $(2.5 \mathrm{~cm}$ ) with a $107 \mathrm{~cm}$ focal length objective lens. Since this represents $f / s t o p s$ of $f / 42$ and up, and light available from most shots requires $f /$ stops to be $f / 22$ or less, it is believed that this combination presents no severe limitation. However, calculations show that a field lens of shorter focal length would reduce vignetting at the smaller magnifications, but probably at the cost of greater distortion.

\section{CONCLUSIONS \& RECOMMENDATIONS}

The Pantex Model 121 Streak Camera optical system has been optimized and a significant improvement over that of the Model 101 has been realized, using available lenses and techniques.

Future improvements might be realized by:

1. Investigating effect of internal magnification on flatness of magnification at the image plane, for a given set of lenses.

2. Investigating effect of field lens focal length on flatness of magnification at the image plane.

3. Selection of better quality lenses, both for use as internal lenses and for use as external objective lenses.

4. Investigating effects of internal aperture size and placement.

5. When available, use MTF measuring equipment to determine ability of total optical system (port glasses, objective lenses, turning mirrors, internal optics, film, processing, analysis) to resolve required information for a given test fire. 


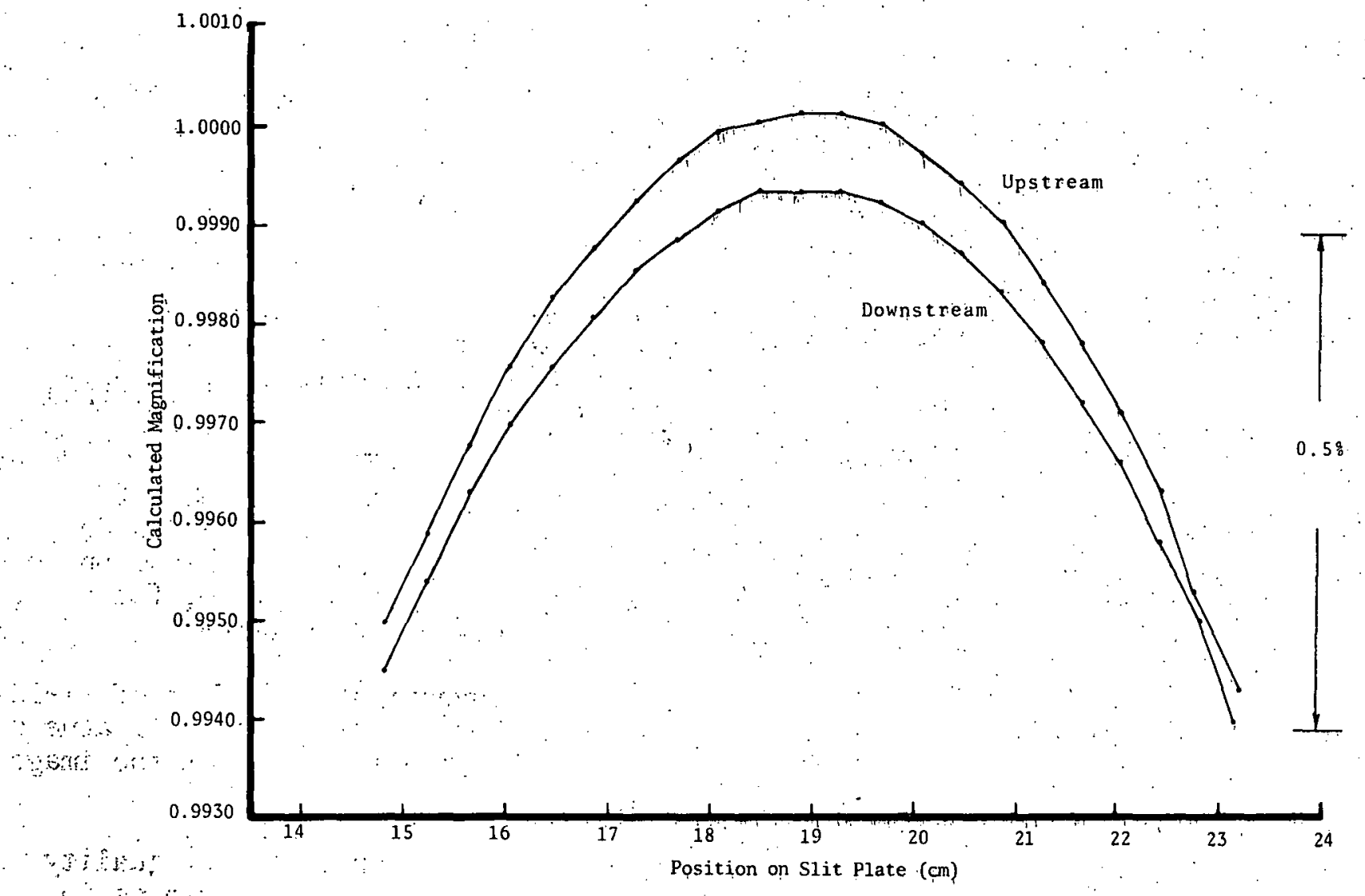
Fig. 3. Calculated Magnification Across S1it Plate Image for Stịll Pictures in Upstręam
and Downstream Positions for Model i 31

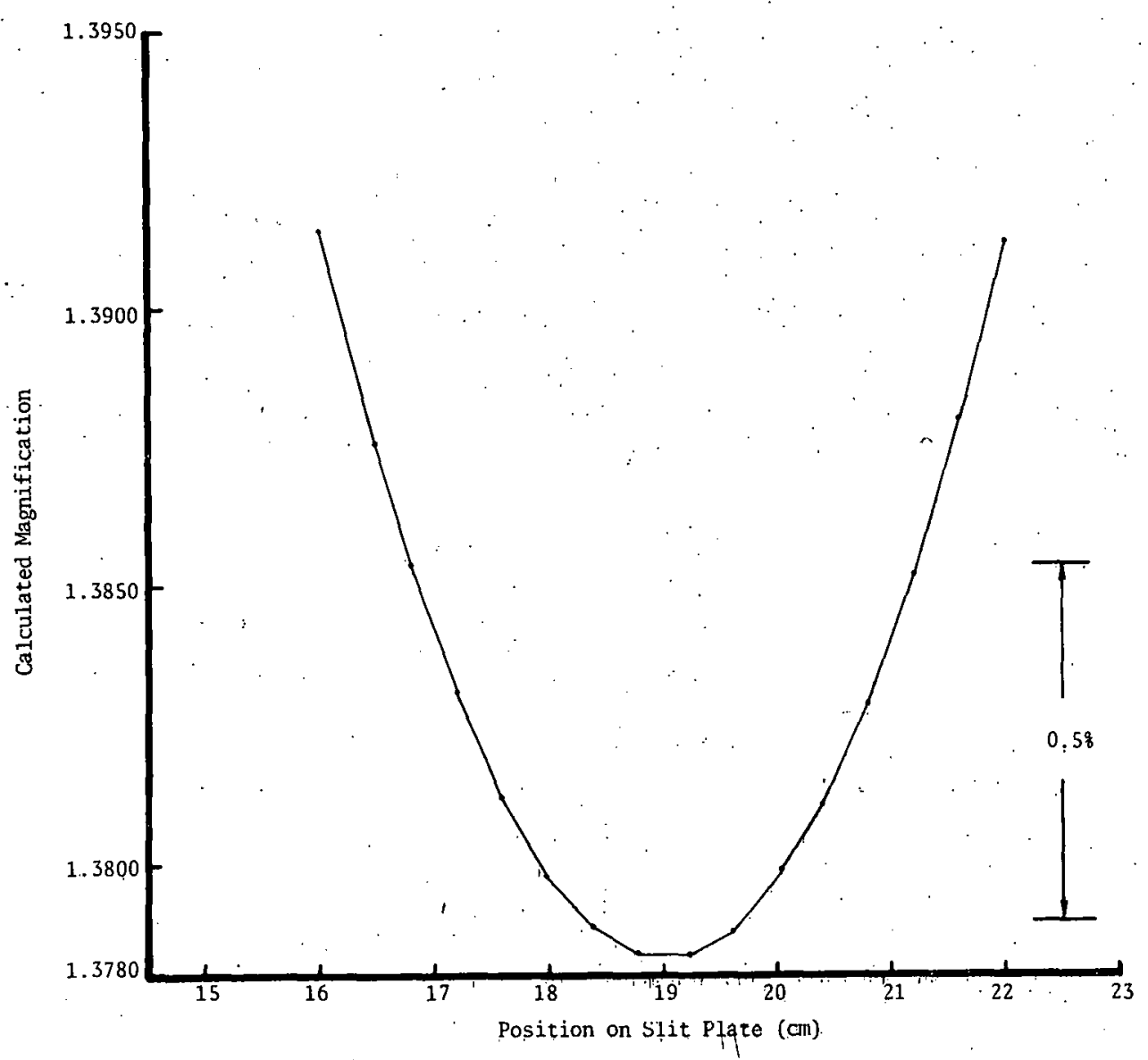

Fig. 4. Calculated Magnification Across Slịt Pląte Image for Still Picture in Upstream Position for Model 101 


\section{DISTŔ IBUT ION}

ALO

V. C. Vespe, Director

Weapons Development Division

R. R. Fredlund, Jr., Director

Classification \& Technical Information

Mound Lab

Director of Explosives

$\underline{\text { SLL }}$

C. S. Selvage - Org. 8180

LLL .

G. L. Dittman (10 Copies)

Attn: R. J. Woodworth

C. T. Brockett, Technical Information Dept.

LASL

E. H. Eyster - WX-DO

R. N. Rogers, Attn: F. B. Baker $-W X-2$

J. Aragon - WX-3

Report Library - ISD-4

\section{SLA}

B. E. Arthur - Org. 1570

J. C. Crawford - Org. 2500/D. H. Anderson Org. 2510

J. C. King - Org. 2300/C. B. McCampbe11 Org. 2310

Central Technical Files - Org, 3141

Uর̣

Jack Kirkham

Atomic Weapons Research Establishment

Aldermaston, Reading, England
PX

Divișion Manager, Mfg. Engineering

Division Manager, Quality

Division Manager, Development (2 copies)

B. H. Carr, E\&TTC

Technical Library

Circulation Copy:

(1) Area Manager, DOE/AAO

(2) Division Manager; Manufacturing $\mathrm{MEH}$

Circulation Copy:

(1) C. R. Poole

(2) Plant Manager

(3) M\&̧H-SM Co,, Inc., Lexington, KY 